\title{
Dealing with the data
}

\section{Washington}

Representatives from the National Institutes of Health (NIH), the Department of Energy (DOE) and Genbank, the national sequence database at Los Alamos National Laboratory, are meeting here this week to draw up recommendations for a new interagency informatics taskforce to oversee national policy on handling the data created by the mapping and sequencing of the human genome. The task-force will put proposals on both policy and technical issues before the NIH genome advisory meeting due to be held in December.

The deputy director of the NIH human genome office, Elke Jordan, warned the audience at an international conference on sequencing at Wolf Trap, Virginia, last month that unless coherent policies plans are developed now, "we are going to run into a big problem later on".

Central to the debate is the role of journals in publishing sequence data. At present Genbank shares with the European Molecular Biology Laboratory (EMBL) in Heidelberg, West Germany, responsibility for searching journals and storing genetic sequences. But Paul Gilna of Genbank says that, with the collaboration of journals, the responsibility for data entry is being shifted to the authors of the publications. An increasing number of journals are making the deposition of sequences in databanks a condition of publication.

But researchers have yet to agree on when they should be required to release data. Genbank is aiming to ensure that deposited data are available within one month of publication, but some researchers advocate delaying the public release of data until the results are refined and interpreted. James Watson, director of the genome office, has suggested that the United States restrict dissemination of its data to reserve any commercial benefit to itself (Nature 341, 269; 1989). Jordan responds that widespread international collaboration makes it almost impossible to restrict dissemination of results, and says the best way to ensure reciprocity in access to data is to refuse to collaborate with those who withhold data.

Despite concern in Congress that funds for the US genome project should not subsidize foreign biotechnology industries, most researchers in the genome project are more anxious to ensure fast dissemination of results, and Jordan said that NIH would consider making it a condition of an NIH grant that the sequencing data be released at a specified time. They might also consider refusing to award grants to researchers who have delayed releasing their results.

The new task force will also, in Jordan's words, try to find "new ways to give brownie points" for research, since the human genome project is likely to create lengthy sequences that will not be publishable in the more traditional journals. Mark Pearson, director of molecular biology at Dupont and head of the NIH informatics committee, says that researchers will increasingly include in their curriculum vitae accession numbers given to them when they deposit data in the databanks.

But with this, he warns, will come come "all the perils and problems" of counting accession numbers and assigning quality weightings to them. Some researchers at the meeting balked at the suggestion that the data from their research might not merit publication. When Graham Cameron of the EMBL databank suggested that sequencing would become a routine task and that only interpretations of the data would merit publication, Sidney Brenner of the Medical Research Council in Cambridge, where researchers are sequencing the genome of the nematode, quickly retorted that if that was the case

\section{Ethical matters}

Paris

Aт a four-day European meeting on Genetic Heritage and Human Rights held in Paris at the end of last month, a series of workshops were devoted to discussions of research on the human genome and its implications, predictive medicine, in vitro fertilization and biotechnology, from both a scientific and an ethical perspective. Participants formulated recommendations dealing with, among other subjects, the freezing of embryos, the psychological dangers of screening for as-yet incurable monogenetic diseases or diseases that appear only later in life, genetic 'fingerprinting', the need to conserve genetic diversity through gene banks and the existing dangers of eugenic choices. A summary of each of the 13 workshops and their recommendations will be published at the end of the year, followed at a later date by more extensive proceedings.

Peter Coles

then perhaps those at the databanks would care to do the sequencing.

Christine McGourty - Databases have prompted correspondence this week, page 114 .

\section{Bulgaria on a learning curve}

\section{London}

THE three-week long 'Ecoforum' convened in Sofia, Bulgaria, as part of the CSCE (Helsinki) process ended last Friday without a final document. As at the earlier CSCE human rights meeting at Vienna, the Romanian delegation refused to agree on a text, objecting to the proposed draft on two counts.

Romania objected to a paragraph in the draft report that would have given informal groups and individual citizens the right to campaign on environmental issues, but demanded the insertion of a clause condemning the building of nuclear plants close to international boundaries a clear reference to Bulgaria's plan to build such a plant on Belyane Island in the Danube.

According to diplomatic sources in Sofia, President Mikhail Gorbachev and President Todor Zhivkov of Bulgaria made last-minute telephone calls to the Romanian leader, Nicolas Ceaucescu, urging him to accept at least a compromise document, but in vain.

To some extent, however, the Romanian refusal was overshadowed by events taking place outside the hall. For the first time in 45 years, Bulgarian citizens were taking part in a demonstration organized at their own initiative. The demonstrators were members of Ecoglasnost, a new environmental group campaigning against proposed hydroengineering works on
Mount Rila and the river Mesta.

When Ecoglasnost was founded earlier this year, it encountered considerable harassment from the Bulgarian authorities, who refused to recognize it as a legally constituted society. During the run-up to the CSCE meeting, pressure from various embassies won the consent of the Bulgarian government to allow Ecoglasnost to organize some "fringe" activities. Nevertheless, on 26 October, there was what was later officially described as a "regrettable" incident, when the police intervened against Ecoglasnost members distributing leaflets.

The offical explanation - as offered by Nikolai Dyulgerov, head of the Bulgarian CSCE delegation - is that the leaflet distributors were not in the place specified for their activities by the city authorities. But there were no arrests, Dyulgerov said; the 22 citizens concerned were simply conveyed by bus to where they should have been. Dyulgerov admitted that "the authorities had exceeded their instructions at times", but said they had been "provoked" by the conduct of some of the citizens.

The "incident", Dyulgerov said, indicates that both sides need to learn the established procedures for protest activities customary in other countries. Both sides, it seems, took his instructions to heart: and last Friday's demonstration passed off without incident. Vera RIch 